\title{
Extraction and Characterization of "Batuan" [Garcinia binucao (Blco.) Choisy] Seed Protein
}

\author{
Elizabeth S. Quevedo', Marivic S. Lacsamana² and Antonio C. \\ Laurena $^{3}$
}

${ }^{1}$ Department of Pure and Applied Chemistry, Visayas State University, Baybay City, Leyte 6521-A, ${ }^{2}$ Institute of Chemistry, University of the Philippines Los Baños College, Laguna, ${ }^{3}$ Institute of Plant Breeding Crop Science Cluster, University of the Philippines Los Baños College, Laguna

\begin{abstract}
"Batuan" [Garcinia binucao (Blco.) Choisy], an indigenous, lesser known member of the Gutifferae family with export potential is underutilized and understudied. The present study was carried out to extract and characterize the protein in "batuan" [Garcinia binucao (Blco.) Choisy] seeds for nutritional quality assessment. Protein content of "batuan" seed meal was $8.9 \pm 0.59 \%$ dry basis. Solubility fractionation of "batuan" seed meal showed globulin and glutelin as the major seed proteins. SDS-PAGE resolved the globulin and glutelin into three groups of polypeptides with molecular weights of about $20-54 \mathrm{kDa}$. Amino acid analysis revealed that seed protein contained all the essential amino acids with leucine as the most abundant while tryptophan, the least. "Batuan" seed proteins were mostly made up of acidic and hydrophobic amino acids with glutamic acid $(2.67 \%)$ as the highest. Nutritional assessments including E/T (38.4\%), amino acid score (1.6\%), predicted PER (3.2-3.7) and estimated BV (98.3\%) suggested that the seed proteins are of good quality. Hence, "batuan" seeds has a promising potential as an important sources of valuable proteins and amino acids for use as food supplement/enhancing ingredient.
\end{abstract}

Keywords: amino acid, "batuan" seed protein, nutritional, tryptophan

Correspondence : E.S. Quevedo Address: Department of Pure and Applied Chemistry, Visayas State University, Baybay City, Leyte6521-A E-mail: elizabethquevedo48@yahoo.com

DOI: 10.32945/atr3625.2014 


\section{INTRODUCTION}

Seed storage proteins which accumulate in high amounts in some plant seeds as sources of nutrients for germinating seeds constitute an important source of dietary proteins for human consumption. In the Philippines, many edible, indigenous, seed-bearing fruit trees which are known only by the local people provide income as well as cheap sources of their dietary proteins. "Batuan", Garcinia binucao (Blco.) Choisy, is one of the lesser-known, indigenous, seed-bearing fruit trees identified with export potential (de la Cruz, 2013). The fruit which is mainly used as souring agent in native dishes contains several (more or less 7) large, edible seeds (Quevedo, 2013; Florido and Cortiguerra, 2003). However, the quality and quantity of the seed protein of "batuan" fruit (Figure 1) remains little if none at all has been published to date. Quevedo (2013) revealed that the protein content of "batuan" fruits is generally low (less than $10 \%$ ) with the seeds containing the highest.

Characterization of the seed storage proteins in "batuan" fruit is important since it is consumed and considered as a favorite souring agent by Filipinos especially in some part of the provinces of Negros Occidental, Iloilo, Leyte, Masbate and in other places in the Philippines (Florido and Cortiguerra, 2003; Cojuangco, 2012; de la Cruz, 2013). During fruiting season, the fruits are processed into various products such as salted puree, jam, jelly, prunes, and candies. Thus, information in terms of protein quality and quantity are very valuable and may make significant contribution to its nutrient quality and processing properties as well as its potential application in food processing. Furthermore, analysis of the seed storage proteins in "batuan" may also provide insight into characterization of genetic diversity, improvement of nutritional quality, and seed development for "batuan".

This article presents the results on the extraction and characterization of the protein in "batuan" seed. "Batuan" seed proteins were evaluated for their relative amount and amino acid composition. An attempt was also made to predict its nutritional quality. 


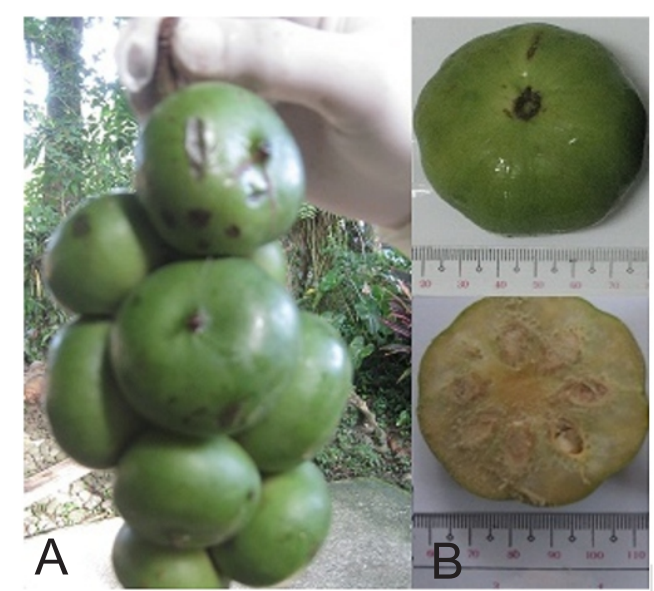

Figure 1. A. The "batuan" [G. binucao (Blco.) Choisy] fruits. B. Cross-section of "batuan" fruit with seeds.

\section{MATERIALS AND METHODS}

\section{Materials}

Seeds of "batuan" were obtained from harvested mature fruits at the Pomology Project of the Visayas State University, Visca, Baybay City, Leyte. The fruits were authenticated from the University of the Philippines Los Baños (UPLB) Museum of Natural History, College, Laguna, Philippines. Analytical grade acrylamide, ammonium persulfate (APS), bis-acrylamide, molecular weight markers 14,400-200,000 Da (BIORAD), bromphenol blue, Coomassie Brilliant Blue G-250, dihydrate hydrogen phosphate, glycine, potassium dihydrogen phosphate, sodium chloride, sodium dodecyl sulfate (SDS), sodium hydroxide, and Trizma base, acetic acid, Bradford reagent, ethanol, hydrochloric acid, beta-mercaptoethanol, $\mathrm{N}, \mathrm{N}, \mathrm{N}^{\prime}, \mathrm{N}^{\prime}$-tetramethylenediamine (TEMED) were procured from commercial suppliers.

The dialysis tubing cellulose membrane (MWCO 12,000) was purchased from Sigma Chemicals.

\section{Preparation of the Defatted "Batuan"Seed Meal}

Dried "batuan" seed endosperm was ground in a blender, then passed through a 40-mesh sieve and defatted using direct solvent (hexane) 
method with constant stirring at room temperature under the fume hood for $24 \mathrm{hr}$. The meal was stored at $5^{\circ} \mathrm{C}$ after removal of hexane and airdrying under the fume hood.

\section{Protein Fractionation}

Storage proteins from the defatted "batuan" seed meal were extracted with stirring at $4{ }^{\circ} \mathrm{C}$ for $1 \mathrm{hr}$ in $1: 20 \mathrm{w} / \mathrm{v}$ water, $0.5 \mathrm{M} \mathrm{NaCl}, 70 \%$ ethanol and $0.1 \mathrm{M} \mathrm{NaOH}$ according to the Osborne solubility procedure (Osborne, 1924). All extractions were carried out twice. Albumin, globulin and glutelin fractions were dialyzed. All protein fractions were freeze-dried, then the dried samples were stored at $5^{\circ} \mathrm{C}$ for subsequent use.

\section{Preparation of Total "Batuan" Seed Protein Extract}

Total "batuan" seed protein was obtained from defatted seed meal by dispersing at 1:2 w/v in $20 \mathrm{mM}$ Tris- $\mathrm{HCl}$ buffer. The mixture was stirred for $2 \mathrm{~h}$ at $4 \mathrm{C}$, centrifuged at $10,000 \mathrm{rpm}$ for $10 \mathrm{~min}$ at $4^{\circ} \mathrm{C}$ and filtered through Whatman No. 4 filter paper. The supernatant was freeze-dried and the dried sample extract was stored at $4^{\circ} \mathrm{C}$ for subsequent use.

\section{Protein Content}

Protein contents in the extract and the Osborne fractions were assayed by Bradford's method (Bradford, 1976) using bovine serum albumin (BSA) as protein standard. Protein concentrations of the samples were calculated using the linear regression formula from the bovine serum albumin (BSA) standard curve.

\section{SDS-PAGE Analysis}

The estimated molecular weights of the polypeptides in the different protein solutions (crude extract and Osborne protein fractions) were determined by the sodium dodecyl sulfate polyacrylamide gel electrophoresis (SDS-PAGE) using $12.5 \%$ polyacrylamide gel according to Laemmli (1970) and low molecular weight protein standard markers (BIORAD). The lyophilized crude extract and Osborne fractions were dissolved in $1 \mathrm{~mL}$ of $20 \mathrm{mM}$ Tris- $\mathrm{HCl}$ buffer at $\mathrm{pH} 8.8$. The solution was then centrifuged at $10,000 \mathrm{rpm}$ for $2 \mathrm{~min}$ at $4^{\circ} \mathrm{C}$ to obtain the purified 
Extraction and Characterization of "Batuan" Seed Protein

sample. Aliquots of the extract and Osborne fractions were added with sample buffer, heated for $5 \mathrm{~min}$ and cooled to room temperature before

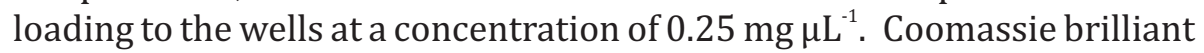
blue R-250 was used for staining.

\section{Amino Acid Analysis}

Dried, powdered, defatted seed endosperm meal sample was sent for amino acid content analysis at the SGS Thailand, Inc. and analyzed following their in-house method based on the protocol for amino acid analysis in the Handbook of Food Analysis Vol. 1 and using Gas Chromatography-Mass Spectrophotometry.

\section{Evaluation of Nutritional Parameters}

The amino acid composition was used to estimate the nutritional value of the protein based on the provisional amino acid scoring pattern for preschool children (WHO, 2007). The parameters such as the proportion of essential amino acids with total amino acids in the protein (E/T \%), amino acid score or chemical score, predicted protein efficiency ratio (PER) and estimated biological value (BV) were used for nutritional quality assessment. PER values were estimated using the regression equations proposed earlier by Alsmeyer et al. (1974) which are outlined as follows:

$$
\begin{aligned}
& \text { PERI }=-0.684+0.456(\text { Leu })-0.047 \text { (Pro }) \\
& \text { PER II }=-0.468+0.454(\text { Leu })-0.105(\text { Tyr }) \\
& \text { PER III }=-1.816+0.435(\text { Met })+0.780(\text { Leu })+0.211(\text { His })-0.944(\text { Tyr })
\end{aligned}
$$

BV of protein in "batuan" seed was estimated using the equation developed by Mørup and Olesen (1976) and is shown below:

$$
B V=10^{2.15} \times q_{l y s}^{0.141} \times q_{p h e+t y r}^{0.60} \times q_{m e t+l y s}^{0.77} \times q_{t h r}^{2.14} \times q_{t r p}^{0.21}
$$

where:

$$
\begin{aligned}
q & =\frac{\text { ai sample }}{\text { ai reference }} \text { for ai sample } \leq \text { ai reference } \\
q & =\frac{\text { ai reference }}{\text { ai sample }} \text { for ai sample } \geq \text { ai reference } \\
\text { ai } & =\text { mg of amino acid per g of total essential amino acids. }
\end{aligned}
$$


Statistical Analysis

Protein content and SDS-PAGE analyses were done in triplicates while amino acid analysis in duplicate. Results on protein content were reported as mean \pm SD.

\section{RESULTS AND DISCUSSION}

\section{Fractionation of "Batuan" Seed Proteins}

The crude protein of "batuan" seed endosperm on moisture free basis was $8.9 \pm 0.52 \%$. Osborne's protein fractionation procedure extracted $92.82 \%$ of the proteins (Table 1) and contained albumin, globulin, prolamin and glutelin. Globulins are the most abundant, accounting for about $67.49 \%$ of the total soluble proteins followed by glutelin $(20.40 \%)$, albumin (3.81\%) and prolamin (1.12\%). This finding is similar to those of Moringa seeds where globulins and glutelins constitute the major storage proteins (Reyes, 2010). Furthermore, there are no previously reported data on the seed storage proteins of "batuan" in the Philippines and from other countries to compare the results of this present work.

Table 1. Seed storage proteins (\%) of "batuan" fractionated using the Osborne solubility scheme.

\begin{tabular}{lcc}
\hline & PROTEIN CONTENT $(\% \mathrm{db})^{1}$ & \% OF TOTAL PROTEIN CONTENT \\
\hline Initial Protein & $8.92 \pm 0.59$ & \\
Total soluble protein & $8.28 \pm 0.61$ & 92.82 \\
Albumin & $0.34 \pm 0.02^{\mathrm{c}}$ & 3.81 \\
Globulin & $6.02 \pm 0.05^{\mathrm{c}}$ & 67.49 \\
Prolamin & $0.10 \pm 0.00^{\mathrm{a}}$ & 1.12 \\
Glutelin & $1.82 \pm 0.54^{\mathrm{b}}$ & 20.4 \\
Nonsolubilized residue & $0.025 \pm 0.00$ & 0.28 \\
Total crude protein & & \\
recovered & $8.305 \pm 0.61$ & 93.1 \\
\hline
\end{tabular}

${ }^{1}$ Average of 3 trials

Means within a column followed by a common superscript are not significantly different at 5\% level, LSD.

\section{Molecular Weight Determination by SDS-PAGE}

The different Osborne fractions from the defatted "batuan" seed meal were further resolved on SDS-PAGE and the electrophoretogram is shown 
in Figure 2. Globulin fractions revealed polypeptides of low molecular weights at approximately 51.85, 27.52 and $20.97 \mathrm{kDa}$. The glutelin fractions also exhibited three prominent polypeptide bands with molecular weights of about $53.92,27.92$ and $21.06 \mathrm{kDa}$.

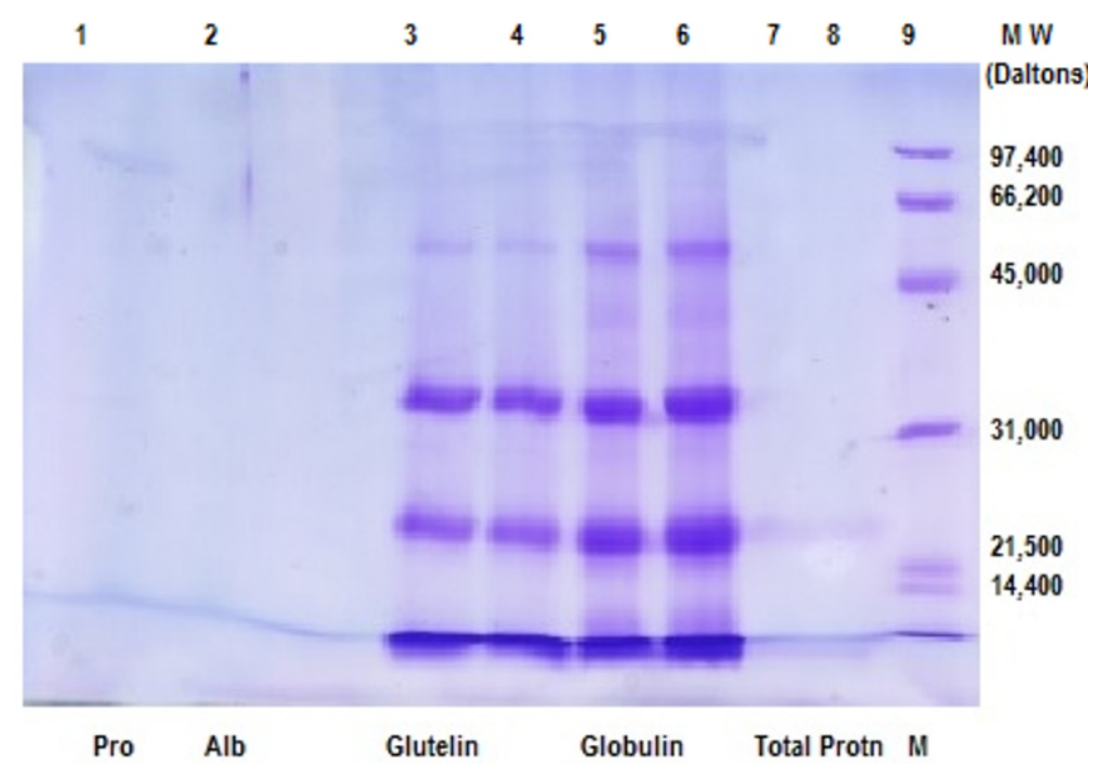

Figure 2. SDS-PAGE of the seed storage protein fractions of "batuan".

Lane: 1- prolamine; Lane 2 - albumin; Lanes 3 \& 4 - glutelins;

Lanes 5 \& 6 - globulin; Lanes 7 \& 8 - total protein;

Lane 9 - protein standard

Meanwhile, no bands were observed in the albumin, and prolamin fractions. This is probably due to the low protein content in the albumin or prolamin fractions. However, it is also possible that the protein content for albumin and prolamin obtained using Bradford assay was an estimate for other compounds such as polyphenols and some alkaloids that were also extracted by the solvents from the seed matrix. These impurities when present in high concentration in the protein sample may have interfered with the assay by associating with the Coomassie dye, giving a response at $595 \mathrm{~nm}$. Compton and Jones (1985) pointed out that bases, detergents and other non-protein compounds when present at high concentration in the protein sample interfere with Bradford assay, resulting in an over estimation of the protein content.

The total protein extract exhibited less prominent polypeptide band of approximately $21.32 \mathrm{kDa}$ identical to the globulin and glutelin bands. The 
result implies that the separation gel buffer (20 mM Tris- $\mathrm{HCl})$ used in the extraction of the total proteins in defatted "batuan" seed meal did not efficiently solubilize most of the proteins present. Probably, the concentration of Tris-HCL in the separation buffer $(20 \mathrm{mM})$ was not enough to isolate the soluble proteins in the endosperm. Tris- $\mathrm{HCl}$ was used as the extractant of the total proteins in the defatted "batuan" seed meal since it is a component of the separation gel of the SDS-PAGE, and has been one of the widely used extraction buffer in protein purification as well as in the extraction of nucleic acids.

Globulins, the most widely distributed groups of storage proteins are oligomeric proteins consisting of 2 or more subunits that can be separated under mild dissociating conditions. Bewly and Black (1994) pointed out that these subunits are composed of a number of polypeptide chains containing variable amino acid sequence between homologous subunits. Based on their sedimentation coefficients, globulins are classified as being the $7 \mathrm{~S}$ vicilin-type and the $11 \mathrm{~S}$ legumin-type which exhibit considerable variation in their structure resulting from post translational processing.

In this study, both the globulin and the glutelin fractions contained three groups of polypeptides with almost similar molecular weights. However, the $53.92 \mathrm{kDa}$ glutelin band was not very visible compared to the $51.85 \mathrm{kDa}$ globulin band which may be due to a lower concentration of glutelin compared to globulin. Analysis of the $21.06 \mathrm{kDa}$ of the glutelin band showed similarity in the molecular weight with the $19-22 \mathrm{kDa}$ basic subunit of rice glutelins (Robert et al., 1985; Kagawa et al., 1998). Several earlier studies reported that glutelins showing variations in structures and molecular weights are also structurally similar to the $11 \mathrm{~S}$ globulins (Zhao et al., 1983; Wen and Luthe, 1985). These observations may also explain the similarity of the number of glutelin and globulin polypeptides obtained in this study. The identities as well as the characteristics of these low molecular weight polypeptides in "batuan" seeds have never been published to date. Thus, more detailed studies to give insights on its characteristics and properties are needed.

\section{Amino Acids Profile}

The amino acids composition of the "batuan" seed endosperm is shown in Table 2. Glutamic acid (2.67\% dry basis) was found as the most abundant amino acid of the "batuan" seed proteins followed by aspartic acid $(0.93 \%)$ and leucine $(0.90 \%)$. This finding is similar with those 
obtained in its close relative, mangosteen, G. mangostana (Ajayi et al., 2013) as well as to other fruit seeds such as tamarind (Glew et al. (1997), and pigeon proteins (Etonihu et al., 2009), with glutamic acid contents of

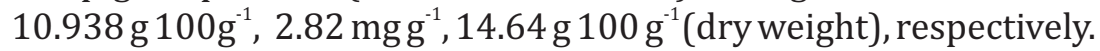

Moreover, the total combined amount (3.6\%) of acidic amino acids was higher than those of the uncharged polar amino acids (1.36\%) and the basic amino acids (0.48\%) and is almost the same as that of the hydrophobic amino acids (3.5\%). This suggests that the proteins in "batuan" seeds and their protein fractions may be of acidic nature. Moreover, the acidic and hydrophobic amino acids in "batuan" seeds are almost equal in proportion. The results suggest that the lower molecular weight polypeptides in "batuan" seeds may have amphiphatic character, having both a hydrophobic region interacting with lipids and a positively charged hydrophilic region interacting with water and other negatively charged residues.

Table 2. Amino acid composition (\% dry basis) of "batuan" [G. binucao (Blco.) Choisy] seeds and the percentage (\%) essential amino acid requirements for preschool children (3-10 years) (WHO, 2007)

\begin{tabular}{lcc}
\hline AMINO ACID & $\begin{array}{r}\text { BATUAN SEED PROTEIN } \\
(\%)^{1}\end{array}$ & $\begin{array}{c}\text { WHO (2007) } \\
(\%)\end{array}$ \\
\hline Valine & 0.52 & 2.9 \\
Leucine & 0.90 & 4.4 \\
Isoleucine & 0.43 & 2.3 \\
Threonine & 0.37 & 1.8 \\
Methionine & 0.15 & 1.8 \\
Phenylalanine & 0.47 & 3.0 \\
Lysine & 0.27 & 3.5 \\
Histidine & 0.21 & 1.2 \\
Tryptophan & 0.11 & 4.8 \\
\hline Total essential amino acids (E) & 3.43 & 20.9 \\
\hline Alanine & 0.43 & \\
Glycine & 0.43 & \\
Serine & 0.25 & \\
Proline & 0.48 & \\
Aspartic acid & 0.93 & \\
Glutamic acid & 2.67 & \\
Tyrosine & 0.27 & \\
Cystine & 0.04 & \\
Total nonessential amino acids (N) & 5.50 & \\
Total amino acids & 8.18 & \\
Classified distribution of amino acids & & \\
1. Hydrophobic & 3.51 & \\
2. Uncharged polar & 1.36 & \\
3. Basic & 0.48 & \\
4. Acidic & 3.60 & \\
\hline
\end{tabular}

${ }^{1}$ Average of 2 measurements 
Murray and Roxburgh (1984) as reported by Tounkara et al. (2013) also revealed that high levels of albumin elevated the sulfur-containing amino acids in chickpea proteins. In the present study, the amount of sulfur-containing amino acids which are most likely associated with albumins were low, supporting the observation of the absence or the presence of trace amount of albumin in "batuan" seed proteins.

Table 2 further shows that "batuan" seed endosperm contains nine essential amino acids with a total combined amount of 3.43\% dry basis. Leucine $(0.90 \%)$ was the most abundant followed by valine $(0.52 \%)$ and phenylalanine $(0.47 \%)$. However, the total essential amino acids in "batuan" seed protein (3.43\%) was lower than the $20.9 \%$ total essential amino acid requirement for preschool children (WHO, 2007) but higher compared to the reported $0.58 \%$ essential amino acids in tamarind seed (Glew et al., 1997). Nonetheless, "batuan" seeds could supply $16.4 \%$ total essential amino acids, $10.6 \%$ total S-containing amino acids and $24.72 \%$ total aromatic amino acids of the reference values as reported by WHO (2007). As pointed out by Krzysciak (2011), the aromatic amino acids, beside their structural function in proteins, are precursors of many important biological compounds including neurotransmitters and hormones in the human body. Atmaon (2004) also reported that the Scontaining amino acids cysteine and methionine are known to possess antioxidant property which is influenced by the type of oxidant stress and the physiological conditions. In addition, leucine, the only dietary amino acid with the capability of stimulating muscle synthesis (Etzel, 2004), having the highest value $(0.9 \%)$ among the essential amino acids in "batuan" seed, could also deliver $20.4 \%$ of required leucine. Thus, the amount of essential amino acids present in "batuan" seeds would be a significant value addition or contribution to its nutritional quality as well as a good complementary source of dietary proteins. At present, there are no previously reported data on the amino acid content of "batuan" seed proteins in the Philippines and from other countries with which the results of this present work can be compared.

\section{Estimation of Nutritional Quality and Quantity}

The nutritional quality of protein is principally determined by its amino acids composition. Certain nutritional parameters were quantified using the amino acid composition (Table 2).

In 1973, the World Health Organizations had suggested the 
provisional amino acid scoring pattern for an ideal protein. The pattern recommends that for a good protein, the E/T ratio should be at least $36 \%$. "Batuan" seed protein exceeded this criterion suggesting that the proteins of "batuan" seed are of good quality. Moreover, the obtained E/T ratio for "batuan" seed proteins is higher compared to the $30.54 \%$ for cassava tuber-associated proteins obtained by Azucena (2005).

Computation of the predicted PER and estimated BV for "batuan" seed protein based on their amino acid composition was very satisfactory. It is clear from the calculated values in Table 3 that the equations developed by Alsmeyer et al. (1974) for predicting PER and by Mørup and Olesen (1976) for estimating $\mathrm{BV}$, originally designed for meat products, were applicable to "batuan" seed proteins. In general, the protein efficiency ratio (PER) below 1.5 implies a protein of low or poor quality, while between 1.5 and 2.0 indicates an intermediate protein quality and above 2.0 means of high quality protein (Friedman, 1996). The predicted PER values for "batuan" seed protein calculated using PER equations I to III (3.2 to 3.7) as shown in Table 3, were in the range of high quality protein and relatively comparable with the reported PER of 3.1 for whole egg, \& higher than the 2.9 for beef, 2.5 for casein \& cow's milk, 2.2 for soy protein, \& 0.8 for wheat gluten (Hoffman \& Falvo, 2004). This implies that the "batuan" seed protein is of better quality.

Table 3. Nutritional evaluation of "batuan" seed proteins.

\begin{tabular}{lc}
\hline NUTRITIONAL PARAMETER & $\begin{array}{c}\text { TOTAL "BATUAN" } \\
\text { SEED PROTEIN }\end{array}$ \\
\hline E/T, \% ${ }^{1}$ & 38.4 \\
\hline Amino acids score $(\%)$ & 1.7 \\
Tryptophan & 5.6 \\
Lysine & 6.2 \\
Methionine + Cysteine & 11.5 \\
Phenylalanine + Tyrosine & 14.7 \\
Leucine & 13.0 \\
Valine & 18.7 \\
Isoleucine & 32.5 \\
Histidine & \\
Predicted Protein Efficiency Ratio & \\
PER I & 3.2 \\
PER II & 3.3 \\
PER II & 3.7 \\
Estimated Biological Value & 98.23 \\
\hline
\end{tabular}

${ }^{1} \mathrm{E} / \mathrm{T}, \%=$ proportion of essential amino acids and total amino acids. Amino acid scores were evaluated using the reported essential amino acid pattern as reference (WHO, 2007). 
The estimated biological value (BV) of "batuan" seed protein was lower compared to the reported $100 \%$ of egg, but higher than the $93 \%$ of milk, $75 \%$ of beef \& fish, $72 \%$ of corn (Whitney \& Flores, 2010), 74\% of soy protein, \& 64\% of wheat gluten (Hoffman \& Falvo, 2004). The high estimated BV of the protein of "batuan" seed suggests that the protein would be efficiently utilized by the body. However, no comparison could be made on the predicted BV of the "batuan" seed protein in other places in the Philippines and other countries due to lack of published studies on nutrient evaluation.

\section{CONCLUSION}

Globulins (67.49\%) and glutelins (20.40\%) were the major seeds storage proteins of "batuan" based on Osborne fractionation scheme and Bradford assay. Three groups of polypeptides in the Osborne's globulin and glutelin fractions with molecular weights ranging from $20-54 \mathrm{kDa}$ were resolved on SDS-PAGE. Glutamic acid (2.67\%) was the most abundant amino acid in "batuan" seed protein followed by aspartic acid $(0.93 \%)$ and leucine $(0.9 \%)$. "Batuan" seed proteins contained more of the acidic amino acid groups $(3.60 \%)$ and the hydrophobic amino acids $(3.51 \%)$ than the uncharged polar (1.36\%) and basic amino acids $(0.48 \%)$. Furthermore, all essential amino acids were present in "batuan" seed protein and leucine $(0.90 \%)$ was the most abundant. Ratio of essential to total amino acids (38.4\%) exceeded the 36\% criterion suggested by FAO/WHO/UNO (1975) for good quality protein. Based on amino acid score, tryptophan $(1.67 \%)$ was the most deficient essential amino acid. Predicted PER (3.2-3.7) of "batuan" seed protein is within the range for efficiently absorbed and utilized proteins. Estimated BV (98.3\%) was also high. Nutritional assessments suggested that "batuan" seed proteins are of good quality and could be a cheap natural source of supplementary dietary protein.

\section{ACKNOWLEDGMENT}

The authors would like to thank the DA-BIOTECH Research Fellowship Program, and the Visayas State University for funding this research; faculty, staffs and students of the Analytical Service and Biochemistry Laboratories, IPB, UPLB and the Quevedo family for their extraordinary and generous help in this study. 


\section{REFERENCES}

AJAYI, I.A., E. IFEDI and V.N. AGHANU. 2013. Amino acid analysis and preliminary toxicological evaluation of Garcinia mangostana seed cake in albino rats. Global J. of Sci. Front. Res. Chem. 13(1).

ALSMEYER, R.H., A.D. CUNNINGHAM and M.L. HAPPICH. 1974. Equations predicting PER from amino acid analysis. Food Technol. 28:34.

ATMAON, G. 2004. Antioxidant effects of sulfur-containing amino acid. Yonsie Med.J 45:776-788.

AZUCENA, V. A. 2005. Biochemical and molecular analyses of tuberassociated proteins in cassava (Manihot esculenta Crantz). Unpublished Ph.D. Thesis. University of the Philippines Los Baños, Laguna, Philippines. p108.

BEWLEY, J. D. and M. BLACK. 1994. Seeds-Physiology of Development and Germination. New York: Plenum Press. 445p.

BRADFORD, M.M. 1976. A rapid and sensitive method for the quantitation of microgram quantities utilizing the principle of protein dye binding. Anal. Biochem. 72:248-54.

COJUANGCO, G.O. 2012. Binukao-A source of my gastronomical treats. In: Inquirer Opinion. Accessed on July 26, 2013 from: http://opinion.inquirer.net/41012/binukau\#ixzz2YcY4mqGr.

COMPTON, S.J. and C.J. JONES, 1985. Mechanism of dye response and interference in the Bradford protein assay. Anal. Biochem. 1512:369374.

DE LA CRUZ, R.T. 2013. Try 'binukaw' for pang-asim. In: Aggie Trends. DA-BAR. 23(2):7, 10.

ETONIHU, A.C., AYODELE, J.T .and M. IBRAHIM. 2009. Proximate and amino acid compositions of wheat species of pigeon pea grown in Kogi State, Nigeria. Nigeria. J. of Biochem. \& Mol. Biol. 24 (2): 32-36.

ETZEL, M.R. 2004. Manufacture and use of diary protein fractions. The J of Nutri. 134:966S-1002S. 
[FAO/WHO] FOOD AND AGRICULTURE ORGANIZATION/WORLD HEALTH ORGANIZATION. 1973. Energy and protein requirements: Report of a Joint FAO/WHO Ad Hoc Expert Committee. WHO Tech. Rep. Series No. 522, Rome.

FLORIDO, H.B. and F.F. CORTIGUERRA. 2003. Lesser Known Edible Tree Species. Res. Info. Series on Ecosyst. Vol. 15. No.3.

FRIEDMAN, M. 1996. Nutritional value of proteins from different food sources. J of Agric'l and Food Chem. 44:6-29.

GLEW, R.H., D.J. VANDERJAGT, C. LOCKETT, L.E. GRIVETTI, G.C. SMITH, A. PASTUSZYN and M. MILLSON. 1997. Amino acid, fatty acid, and mineral composition of 24 indigenous plants of Burkina Faso. J. Food Compo. and Anal. 10:205-217.

HOFFMAN, J.R. and M.J. FALVO. 2004. Protein-which is best? J. of Sports and Med.3:118-130.

KAGAWA H., HIRANO, H. and F. KIKUCHI. 1998. Variation of glutelin seed storage protein in rice (Oryza sativa L.) Japanese J. of Breeding. 38: 327-332.

KRZYSCIAK, W. 2011. Activity of selected aromatic acids in biological systems. Acta Biochemica Polonica 58:461-466. Available on: http://www.actabp.pl/pdf/4_2011/461.pdf

LAEMMLI, U.K. 1970. Cleavage of structural proteins during the assembly of the head of bacteriophage T4. Nature 227: 680-685.

MØRUP, I.L.K. and E.S. OLSEN. 1976. New method of prediction of protein value from essential amino acid pattern. Nutr. Rep. Int. 13:355.

MURRAY, D.R. and C.M. ROXBURGH. 1984. Amino acid composition of the seeds albumin from chickpea. J of Sci. of Food and Agric. 35:893-896.

OSBORNE, T.B. 1924. The vegetable proteins. Longmans, Green, London. 
Extraction and Characterization of "Batuan" Seed Protein

QUEVEDO, E.S., LAURENA, A.C. and F.E.MERCA. 2013. Physicochemical properties, nutritional and sensory quality of "batuan" [Garcinia binucao (Blco.) Choisy] Fruits. Annals of Trop. Res. 35(2):1-21.

REYES, A.C. 2010. Biochemical and molecular studies of Moringa (Moringa olifera Lam.): seed storage proteins and DNA fingerprinting. Unpublished MS Thesis. University of the Philippines.

ROBERT, L.S., NOZZOLILLIO, C. and I. ALTOZAR. 1985. Homology between rice glutelin and oat $12 \mathrm{~S}$ globulin. Bioch. et Biophysic. Acta. 829(1): 1926.

WEN, T.N. and D.S. LUTHE. 1985. Biochemical characterization of rice glutelin. Plt. Physiol. 78: 172-177.

WHITNEY, E. and S. FLORES. 2010. Understanding nutrition. 12 edn. Wadsworth, USA: Cengage Learning. p742.

[WHO] WORLD HEALTH ORGANIZATION. 2007. Protein and amino acid requirements in human nutrition. Report of a Joint WHO/FAO/UNU Expert Consultation. WHO Technical Report Series 935. FAP/WHO/UNO. Geneva, Switzerland.

ZHAO, W.M., GATEHOUSE, J.A and D. BOULTER. 1983. The purification and partial amino acid sequence of a polypeptide from the glutelin fraction of rice grains; homology to pea legumin. FEBS Letters. 162: 96-102. 